\title{
Upper Pleistocene blow flies (Diptera: Calliphoridae) trapped in fossilized crania of large mammals discovered from gravel pits in the Rhine rift valley from Hesse (Germany)
}

\author{
Bastian Mähler, Torsten Wappler, Mayuran Sanmugaraja, \\ Frank Menger, and Wighart von Koenigswald
}

\begin{abstract}
Fossil blow fly remains, discovered from cranial fragments of four Upper-Pleistocene large mammals (two Mammuthus primigenius, one Megaloceros giganteus and one Bos primigenius), could be identified as puparia of Protophormia terraenovae (Robineau-Desvoidy). The material was discovered from fluvial deposits of the ancient Rhine near Darmstadt (Hessen, Germany). The preservation of the puparia is exceptional. The four individuals of large mammals died separately, but all cadavers lay for a certain time likely on dry ground or were sitting by or in shallow water or sediments in an approximated temperature of $10^{\circ} \mathrm{C}$ or higher (based on current data). During the decomposition, the cadavers were colonized by gravid blow flies, which deposited eggs on natural body orifices and open wounds. Larvae hatched, fed on moist tissue, passed all larval stages and pupated. Shortly after the emergence of the fully developed blow flies, mammal remains were submerged and embedded. Thus they were trapped for fossilisation. Most individuals of Protophormia terraenovae found inside the cranial fragments of Megaloceros giganteus had died inside their puparia maybe as a consequence of freezing, drowning or smothering.
\end{abstract}

Bastian Mähler. Steinmann-Institut für Geologie, Mineralogie und Paläontologie, Universität Bonn, Nussallee 8, 53115 Bonn, Germany. bastian.maehler@uni-bonn.de

Torsten Wappler. Steinmann-Institut für Geologie, Mineralogie und Paläontologie, Universität Bonn, Nussallee 8, 53115 Bonn, Germany. twappler@uni-bonn.de

Mayuran Sanmugaraja. Steinmann-Institut für Geologie, Mineralogie und Paläontologie, Universität Bonn, Nussallee 8, 53115 Bonn, Germany. mayuran.sanmugaraja@gmx.de

Frank Menger. Hintergasse-Str. 23, 68649 Groß-Rohrheim, Germany. bensheim@olfsv.de

Wighart von Koenigswald. Steinmann-Institut für Geologie, Mineralogie und Paläontologie, Universität Bonn, Nussallee 8, 53115 Bonn, Germany. koenigswald@uni-bonn.de

Keywords: Protophormia terraenovae; puparia; taphonomy; carcass; fossil insects

Submission: 29 October 2015 Acceptance: 3 April 2016

Mähler, Bastian, Wappler, Torsten, Sanmugaraja, Mayuran, Menger, Frank, and von Koenigswald, Wighart. 2016. Upper Pleistocene blow flies (Diptera: Calliphoridae) trapped in fossilized crania of large mammals discovered from gravel pits in the Rhine rift valley from Hesse (Germany). Palaeontologia Electronica 19.2.13A: 1-12

palaeo-electronica.org/content/2016/1461-forensic-palaeoentomology 


\section{INTRODUCTION}

Blow flies and other necrophagous insects, play an important role in the decomposition of exposed cadavers and vertebrate remains (Amendt et al., 2004; Szpila, 2010). This phenomenon is also known from the fossil record but rarely documented. They occur in combination with Pleistocene mammal remains from deposits of the Rhine River and shed light on the taphonomy of these carcasses in a wide spread fluvial environment. In the floodplain of the Rhine near Darmstadt (Rhine rift valley) sands and gravels are industrially excavated and produce remains of diverse Pleistocene fauna and flora since the eighteenth century. In the northern part of the Rhine rift valley interglacial and glacial sediments are deposited in superposition containing a rich mammalian fauna. A lower level contains Elephas antiquus, Hippopotamus amphibius, Bubalus murrensis and Dama sp. and is assigned to the last interglacial, whereas Mammuthus primigenius and Coelodonta antiquitatis represent the last glacial. Hyaena and Panthera, the top predators, occurred in cold and warm environments (Koenigswald, 1988). Among the floral remains, thick trunks of Quercus and wood of Ulmus, Fraxinus and Alnus characterise sediments of the interglacial stage, whereas during the cold stages conifers like Pinus and Larix dominated, if climatic conditions allowed trees to grow (Schoch, 1988). Some of the preserved tree trunks show traces of wood boring insects (e.g., Xyloterus lineatus [Scolytinae, Curculionidae], Buprestis sp. [Buprestidae] and others) (Klinger and Koenigswald, 1984). However, the industrial exploitation using floating dredger machines create difficulties in assigning individual specimens exactly to stratigraphy levels. Thus, the reconstruction of the ecological communities remains uncertain.

Among the many remains of Pleistocene mammals in the gravel pits of Groß-Rohrheim and Geinsheim (near Darmstadt, Germany; Figure 1), fossilised puparia of blow flies (Figure 2) were found in the pneumatized cavities of cranial remains (Figure 3). One of Mammuthus primigenius from Geinsheim (Figure 3.1) provided 94 puparia, whereas another one from the gravel pit in Groß-Rohrheim a single puparium. Nine puparia were found in a cranium of Megaloceros giganteus (Figure 3.2) and 19 puparia in a horn core of Bos primigenius (Figure 3.3). Although these species may occur in the same biotope, they may come from different stratigraphic levels. Despite these difficulties, the discovery of the blow flies sheds light into the taphonomic situation as to how these

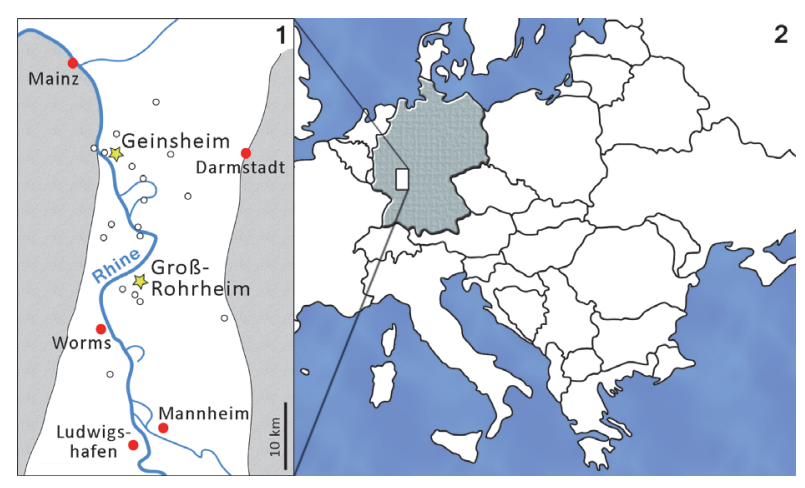

FIGURE 1. Locality map of important gravel pits of the Rhine rift valley between Mainz and Ludwigshafen. 1.1 Locality of the Rhine rift valley in Germany. 1.2 Gravel pits are marked with white spots; gravel pits of Geinsheim and Groß-Rohrheim are marked with a yellow star.

fossils became fossilized. The record of these Pleistocene puparia, interpreted by the current perception of recent forensic entomological studies (Catts and Goff, 1992), support the role of necrophagous insects as "biological clocks" and demonstrate their value for palaeo-entomological studies. The basis for an interpretation are the biological data of the blow flies known from actual observations. The immature stages of flies, ranging from their eggs, larvae and puparia, are used in forensic sciences to estimate the postmortem interval (PMI) in humans (Kabkaew et al., 2007). For the time up to about 72 hours after death there are several methods that can be used by medical examiners to determine the PMI. But after this specific period of time, forensic entomology is the only and most accurate method for PMI determination (Kashyap and Pillay, 1989; Anderson, 2001; Bourel et al., 2003). Necrophagous insects are attracted by specific states of decay and particular species colonize a cadaver for even a limited period of time (Benecke, 1998). For example, the first waves of colonizers are blow flies (Warren, 2006), which can normally be found on carcasses during the first three months (Smith, 1986). Some of these early colonizers are the blow fly species Calliphora vicina [Robineau-Desvoidy], Calliphora vomitoria [Robineau-Desvoidy], Lucilia sericata [Meigen], Phormia regina [Meigen] and Protophormia terraenovae [Robineau-Desvoidy] (Reiter and Wollenek, 1983). Coupled with knowledge of growth rates under specific environmental conditions this faunal evidence provides quite a good estimation of time since death (Benecke, 1998). Besides affecting insect development the ambient temperature is an important point that affects the decompo- 

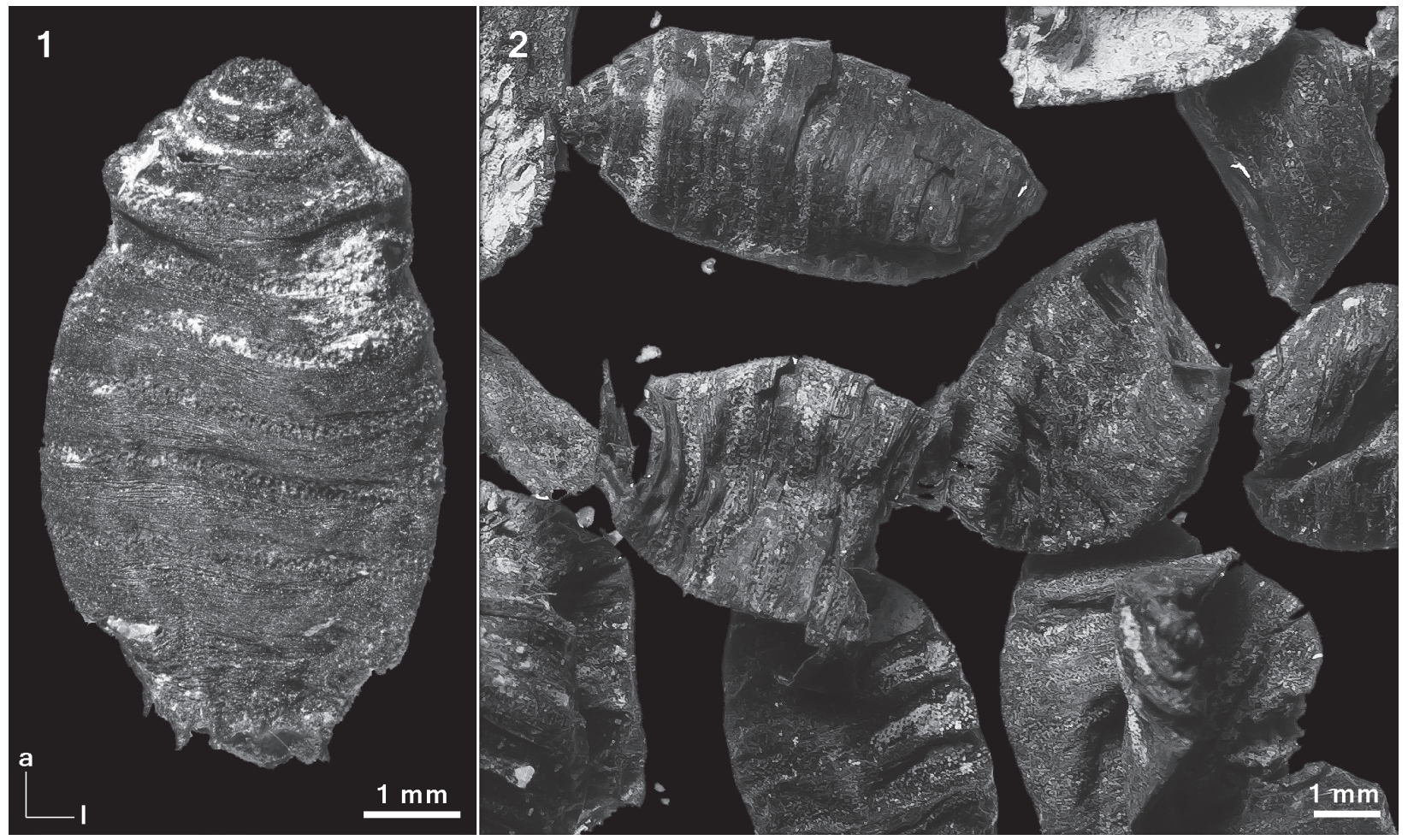

FIGURE 2. Hardened skins of upper Pleistocene puparia of Protophormia terraenovae. 2.1 A fossil puparium in dorsal view. 2.2 Mass of fossil puparia discovered from the cranial fragment of Mammuthus primigenius (Geinsheim). a anterior; I lateral. Photo by Georg Oleschinski.

sition process (Pohjoismäki et al., 2010). Combining such forensic tools with archaeological excavations has given rise to a discipline dubbed, 'archaeoentomology'. Even though encompassed within the broad range of bioarchaeological sciences archaeoentomology remains an underdeveloped, marginal discipline, but one that is becoming increasingly important (Huchet, 2014). The same is true for palaeontological excavations where the activity of different arthropod groups is expressed by osteolytic lesions. Most of the data concerning the osteophagy of certain insects are accounts of multiple osteolytic lesions on dinosaur bones (e.g., Paik, 2000; Roberts et al., 2007; Britt et al., 2008; Chin and Bishop, 2008; Bader et al., 2009), or on extinct forms of terrestrial mammals (e.g., Martin and West, 1995; Kaiser, 2000; Laudet and Antoine, 2004; Dominato et al., 2009; Holden et al., 2013).

During the past years several fossil and subfossil Holarctic blow flies (Protophormia terraenovae) were published from archaeological settings or palaeontological records. One example of such are the fossil remains of the Holarctic blow fly Protophormia terraenovae, which were found in the skull cavity and the horn-core of a steppe wisent
(Bison priscus) near Zemst in the province of Brabant (Belgium). The skull was discovered in coarse fluvial deposits (Gautier and Schumann, 1973), a similar setting as the one reported here. Other fossil remains of Protophormia terraenovae were found in the skull of a woolly rhinoceros, Coelodonta antiquitatis, from Dendermonde (Gautier, 1975, 1995). In Bottrop and Valburg more than 120 puparia were found in the cavities of two mammoth skull fragments (Heinrich, 1988). Böhme (2010) also discovered some remains of the same blow fly species in the neural canal of a thoracic vertebra from a straight-tusked elephant from the interglacial lake sediments of Neumark-Nord in Germany. Fossil blow fly puparia of Protophormia terraenovae were found in the skull fragments of Mammuthus primigenius from the Eurogeul area at the coast of the province South Holland (Plicht et al., 2012; Langeveld and Mol, 2015). The preservation is much better in loess deposits of the permafrost area of Yukon (Canada), north of the Arctic Circle. Therefore fossil puparia of blow flies occur there frequently (G. Zazula, personal commun., 2015) However, unlike in forensic investigations, the elements in question can rarely be examined in situ. 


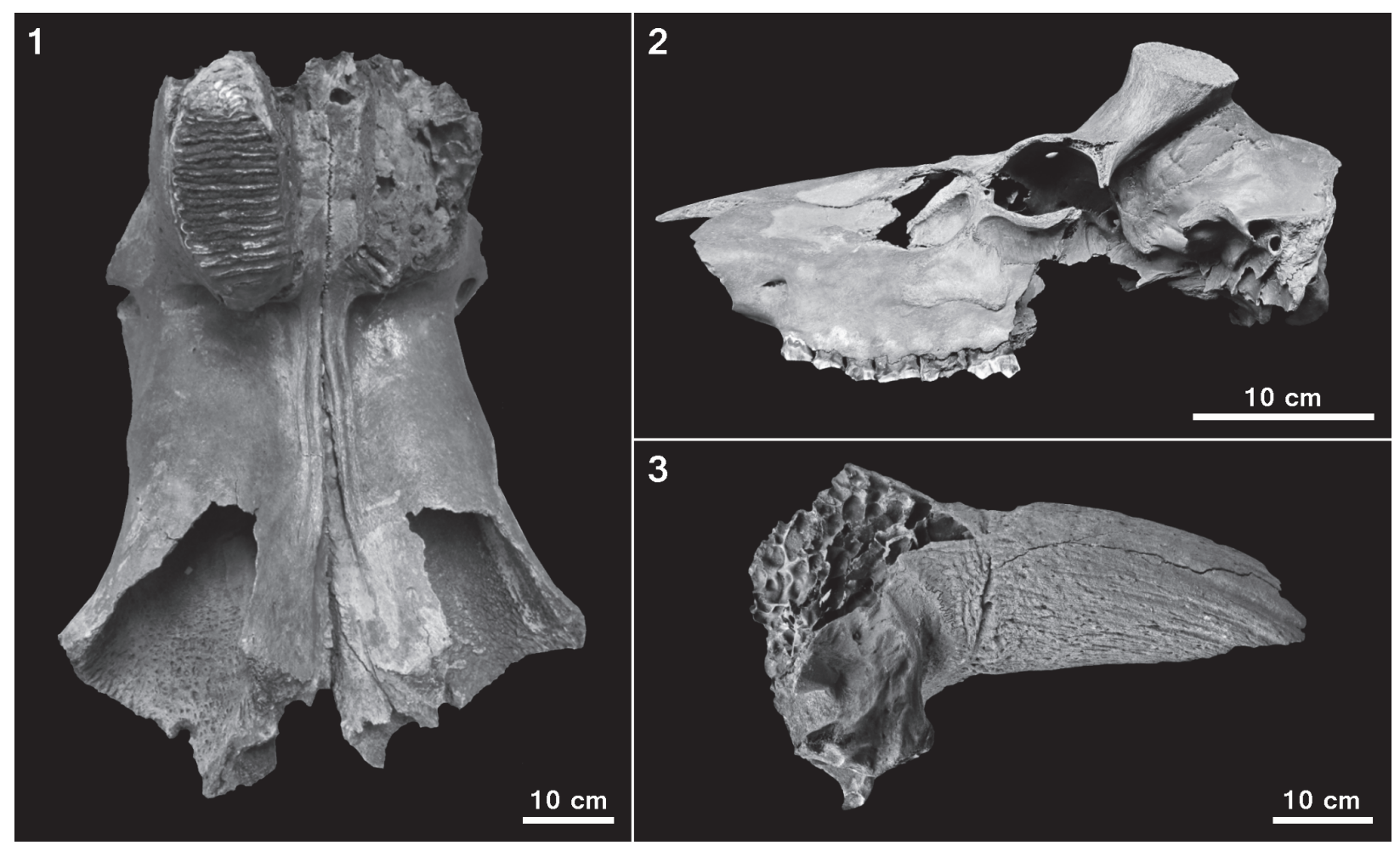

FIGURE 3. Cranial fragments of three Pleistocene mammals containing fossilised puparia. 3.1 Maxilla with left molar of Mammuthus primigenius from Geinsheim (ventral view), 3.2 Nearly complete skull of Megaloceros giganteus from Groß-Rohrheim without lower jaw and antler rose (lateral view), 3.3 Horn core with part of the cranium from Bos primigenius from Groß-Rohrheim (ventral view).

\section{MATERIALS AND METHODS}

One hundred and twenty-three puparia were found in various crania, as mentioned above, by chance during the washing and dry cleaning of the fossil bones by one of the authors ( $F$. Menger), who collected the Pleistocene bone material from the gravel pits since several decades. The puparia were recognized within the air filled spongy structure of the crania that is large in elephant skulls and extends in bovids into the horn cores.

The puparia were sonographically cleaned and then photographed using a stereo-zoommicroscope (Axio Zoom V.16). Afterwards they were scanned by an 'environmental' SEM unit (TESCAN VEGA) to visualize specific ultra-structural details of the puparia. Some intact puparia were carefully opened and their inner parts were removed. The opening of the puparia was not possible without destruction. Afterwards, the contents were investigated using a microscope (Stemi, 2000) and also scanned by an 'enviromental' SEM unit to identify these minute components. One puparium was investigated using a phoenix|x-ray v|tomex s 180 micro-computer-tomography scan- ner (GE Measurement \& Control, Wuntsdorf, Germany) housed at the Steinmann-Institut für Geologie, Mineralogie und Paläontologie (StIPB), Universität Bonn. The data set has a resolution of 5 $\mu \mathrm{m}$; the scan was carried out at $112 \mathrm{kV}$ and 112 $\mu \mathrm{A}$. The CT data were processed using the software Studio Max 2.0 (Volume Graphics, Heidelberg, Germany) and Avizo 7.1 (FEl Visualization Sciences Group, Burlington, MA) to visualize the entire cephaloskeleton located inside the anterior part of the puparium.

\section{Identification of the fossil puparia}

The fossil puparia are grey to greyish brown in colour. Most of them are fragmentarily preserved and some are flattened. Nevertheless, an identification up to the species level was possible. It is based on the comparison to extant samples and the identification key for puparia of forensic important blow flies (Reiter and Wollenek,1983) and the identification key of third instars of European and Mediterranean blow flies of forensic importance (Szpila, 2010).

Figure 4 shows some parts of fossil puparia (left) in comparison to extant samples (right). The 


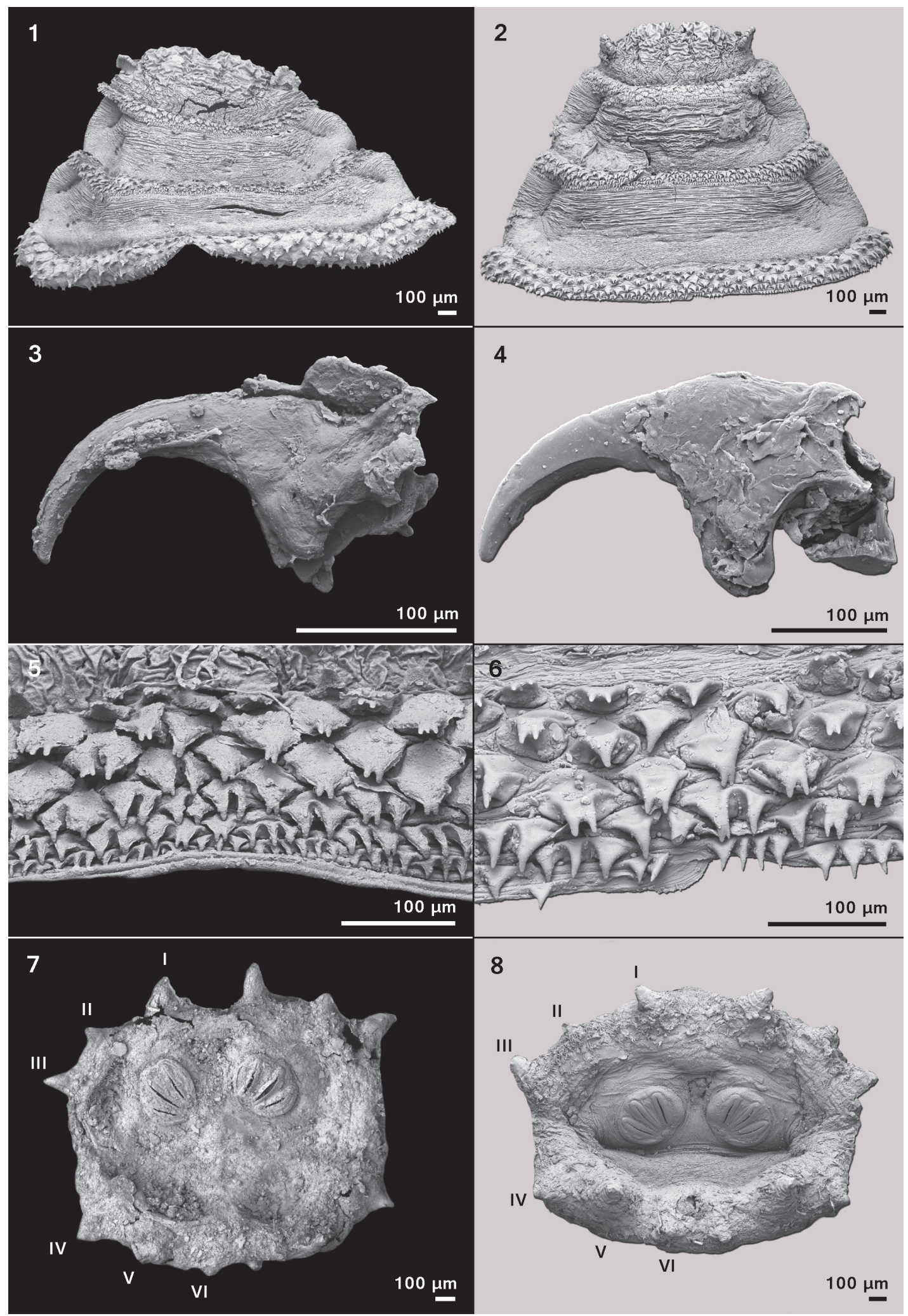

FIGURE 4. SEM-images of fossil remains $(4.1,4.3,4.5,4.7)$ in comparison of similar parts of the puparia of extant Protophormia terraenovae $(4.2,4.4,4.6,4.8)$. 4.1-2 Segment 1-4 of puparia, 4.3-4 mouth hooks of larvae, 4.5-6 spines of thoracic segment 3 show triangular structure with mainly one or two tips and a broad base, 4.7-8 anal division with six pairs of large papillae (I-VI) and two posterior stigmata of circular structure containing three spiracles. 


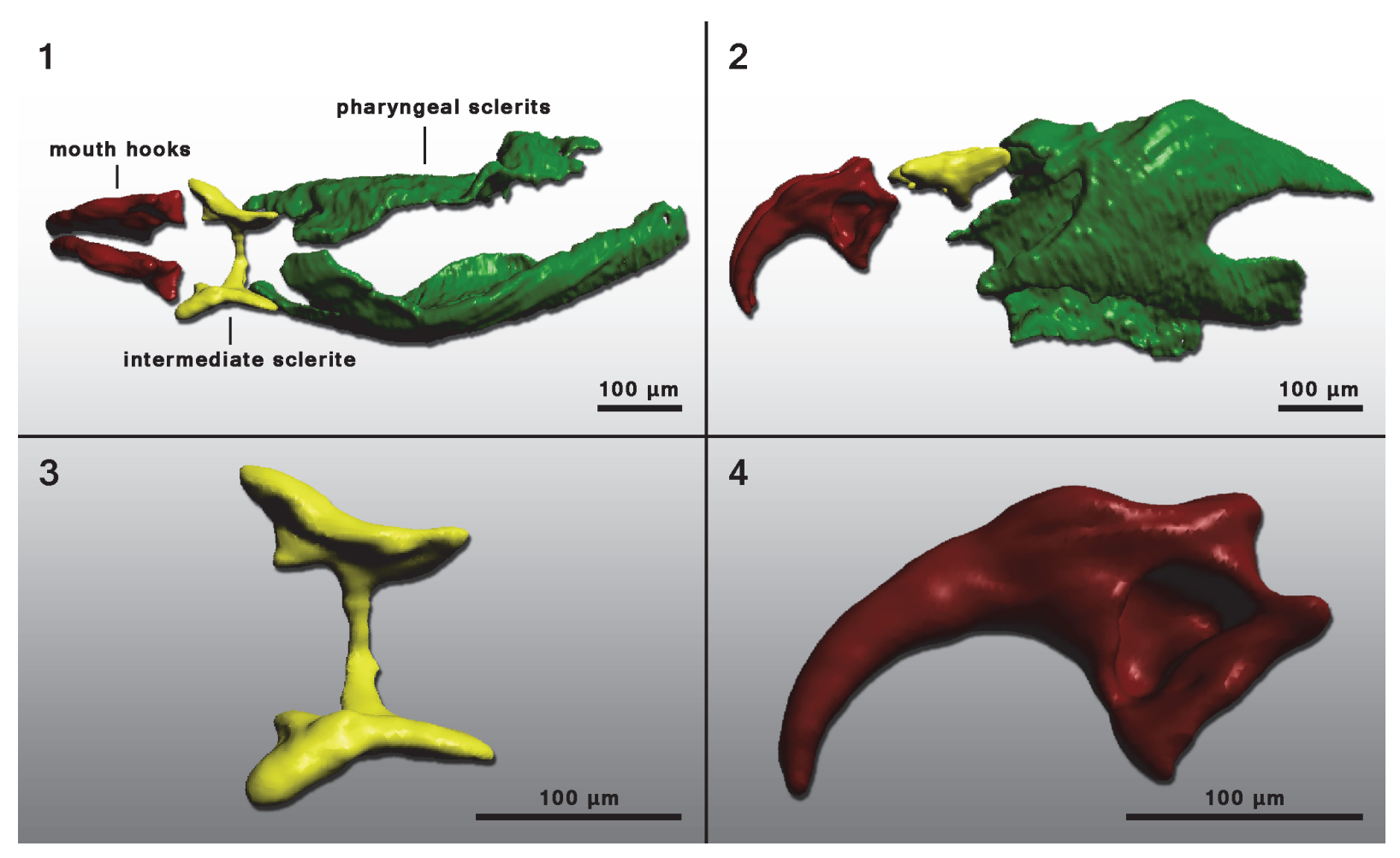

FIGURE 5. 3D-models of parts of the cephaloskeleton reconstructed from fossil puparia. 5.1 entire cephaloskeleton (dorsal view), 5.2 entire cephaloskeleton (lateral view), $\mathbf{5 . 3}$ intermediate sclerite (dorsal view), $\mathbf{5 . 4}$ left mouth hook (lateral view). Available as animation online palaeo-electronica.org/content/2016/1461-forensic-palaeoentomology.

puparia were approximately $6-8 \mathrm{~mm}$ in length. Precise length and diameter were difficult to determine due to loss of puparium segments one to four, or loss of anal division, or puparia are flattened or shrivelled. At the anterior part of some fossil puparia the cephaloskeleton of the blow fly larvae could be found. An oral sclerite of the cephaloskeleton is absent. Mouth hooks are well preserved and show a similar morphological structure as those of extant samples of Protophormia terraenovae (Robineau-Desvoidy) (compare Figure 4.3 and also Figure 5). Spinose bands are well preserved, and spines show a triangular structure with mainly one or two tips and a broad base (Figure 4.5). The spiracular field on the posterior part of the puparia is flat to concave, with two posterior stigmata of circular structure and containing three spiracles (Figure 4.7). On the upper margin of the posterior spiracular field six pairs of large papillae could be identified with papilla II smaller than papillae I and III (Figure 4.7). Based on the examination, the characteristics of the fossil puparia indicate that they belong to the species Protophormia terraenovae (Robineau-Desvoidy) as it was assumed after the investigation of the mouth hooks.
Five of the nine puparia found in the cranium of Megaloceros giganteus turned out to provide even more details. They were filled with hairy and bristly structures. This is also the case in two of 19 puparia found in Bos primigenius and the puparium found in Mammuthus primigenius (GroßRohrheim). One of 94 puparia found in the skull cavities of Mammuthus primigenius (Geinsheim) was also filled. After dismantling these structures some adult blow fly remains could be identified. The first sample (Figure 6.1.1) shows a lot of microtrichia and a cluster of sockets without setae on the whole surface. The structure is $\sim 1.2 \mathrm{~mm}$ in length and $\sim 0.2 \mathrm{~mm}$ in width, whereby the anterior and posterior parts are broken. But the proportion of length and width leads us to the assumption that it is a part of a fly tibia. The second structure (Figure 6.1 .2 ) is $\sim 0.79 \mathrm{~mm}$ in length and $\sim 0.16 \mathrm{~mm}$ in width. A "joint head" at the proximal part and a cluster of hairy structures at the ventro-proximal side lead us to the assumption that this structure is the probasitarsus ( $\mathrm{t} 1$ ) of a fly leg. The third sample (Figure 6.3) shows stem like structures with many branches, which look familiar to the peritrema of a 


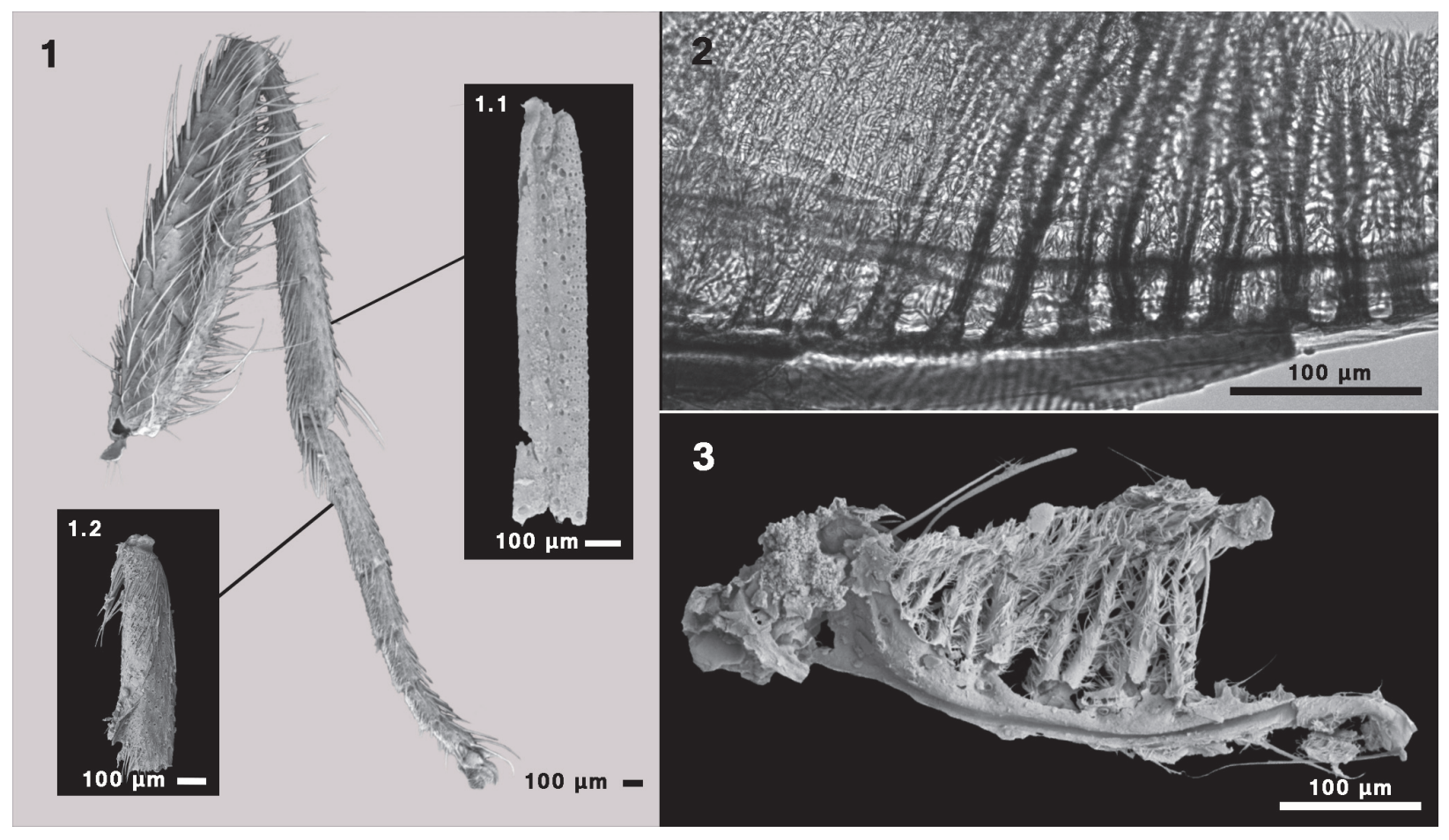

FIGURE 6 SEM-images $(6.1,6.3)$ and microscopic-image $(6.2)$ of adult blow fly remains. 6.1 Leg of the extant blow fly Calliphora vicina and corresponding parts of the leg of fossil Protophormia terraenovae [6.1.1 upper part of the tibia, 6.1.2 probasitarsus (t1)], 6.2 Part of the mesothoracic spiracle of extant Calliphora vicina, 6.3 Fossil part of the mesothoracic spiracle of Protophormia terraenovae.

mesothoracic spiracle, including dense cuticular filter lamellae.

\section{DISCUSSION}

Research in the field of forensic entomology bears important perceptions for criminal investigations. Especially findings about the lifecycle, behaviour and insensibility of the blow fly Protophormia terraenovae are helpful for interpreting the palaeontological findings which are presented here. Protophormia terraenovae is one of the early colonizers on carcasses, which depend on relatively fresh and moist tissues (Benecke, 2007). This species has a holarctic distribution and is very common in cooler regions (Smith, 1986), where it seems that individuals prefer breeding in larger carcasses as a survival tactic (Greenberg and Tantawi, 1993). Protophormia terraenovae heavily depends on climate conditions and temperature (Amendt et al., 2005), with a lower threshold temperature for egg hatching of $10.3^{\circ} \mathrm{C}$ (Warren and Anderson, 2013). Individuals of this species are able to survive submergence for a few days (Singh and Greenberg, 1994) or burial (Balme et al., 2012) inside their puparia.
The sediment inside the skulls and the state of skull preservation of Bos primigenius, Megaloceros giganteus, Mammuthus primigenius (GroßRohrheim) and Mammuthus primigenius (Geinsheim) were evaluated. The fossil blow fly remains of Protophormia terraenovae found among the sediments from the skull cavities raise a special interest.

\section{Colonization of carcasses and submergence}

The cause of death of the mammals is quite uncertain, but a natural death is assumable, as well as a killing by a predator like Crocuta spelaea or Panthera leo spelaea. Both have been also reported for this area (Koenigswald, 1991). Furthermore, animals may have been drowned in the ancient Rhine during flood events.

At the onset of death bodies normally start to decay by an autolytic process caused by endogenous enzymes, followed by anaerobe and aerobe bacterial activity (Krause and Jachau, 2007). If carcasses are exposed and accessible for insects they offer an ideal environment for a variety of species whereby the colonisations are dependent on ecological and biological preferences (Amendt et al., 2005; Benecke, 2005). Ammoniacal sub- 
stances and hydrogen sulphides are produced during the putrefaction, whereby blow flies are attracted (Amendt et al., 2005). Depending on the temperature and weather, gravid blow flies (Calliphoridae) deposit their eggs after few hours or days (Amendt et al., 2005; Benecke, 2005). They prefer natural body orifices (eyes, nose, mouth, ears and anus) and fresh wounds (Amendt et al., 2005; Schoenly et al., 2006). First instars hatch and start to feet on relatively fresh and moist tissue (Benecke, 2007). During this feeding period, three larval stages have passed. After larvae reached the end of the third larval stage, they leave their breeding medium and begin to pupate. Afterwards they finish their life cycle by emergence of the puparium as fully developed blow flies (Amendt et al., 2005).

In contrast to most of the other calliphorids, which generally leave a carcass for pupation (Amendt et al., 2005), larvae of Protophormia terraenovae often pupate on the breeding medium (Busvine, 1980; Warren, 2006). The here presented cases show that third instars migrated into skull cavities of described mammals and additionally into the horn core of Bos primigenius and reached the pupal stage (those on Mammuthus primigenius [Groß-Rohrheim] and Megaloceros giganteus), or even completed their development (most of those on Bos primigenius and Mammuthus primigenius [Geinsheim]). It is assumed that carcasses lay for a certain time on dry ground or were sitting by or in shallow water or sediments. Because a colonization of carcasses by blow flies, while floating at the water surface of the river might be possible, but is quite atypical and seldom occurs (Hobischak and Anderson, 2002; Anderson and Hobischak, 2004). In order to preserve the puparia inside the skulls, where they were protected against mechanical damage, mammal remains got shortly submerged after the emergence of blow flies, maybe caused by a river flooding, and were transported by running water until they were embedded. Because, precise indications for a transport by running water are missing, a short transport cannot be excluded. Further on, the skulls might be covered with skin during the transport.

\section{Minimum temperature during the decomposition}

Adequate temperatures for the development of blow flies occur during cold and warm periods of the Pleistocene, perhaps excluding the period of the Late Glacial Maximum. Temperatures limiting the development of blow flies is not the annual mean but related to the actual temperatures during days or weeks. They may have been quite favourable during summer times even in cold periods.

Based on the discoveries of large mammal fossils (Koenigswald, 1988), as well as the lithostratigraphic considerations (Schweiss, 1988) and pollen analyses by Beug (1988), the gravel pits of Groß-Rohrheim and Geinsheim were assigned to the upper Pleistocene (Eemian interglacial and early Weichselian glacial). In that case, mammals like Hippopotamus amphibius and Bubalus murrensis, as well as botanical discoveries of warm adapted species, a mild Atlantic climate during the last interglacial is assumed.

This indication leads us to the assumption that cranial fragments of Mammuthus primigenius were discovered from fluvial deposits of the early Weichselian glacial, due to mammoths' cold climate adaptions (dense wooly fur and small ears). The specimens of Bos primigenius and Megaloceros giganteus inhabited during the Eemian interglacial as well as during the early Weichselian glacial. Whereas an allocation to a time period is rather difficult.

The development of extant blow flies is highly temperature dependent and does not occur at temperatures below the so called "minimum temperature threshold" (Warren and Anderson, 2013) which is different for individual developmental stages (Anderson and Warren, 2011) what is also assumed for Pleistocene blow flies. Marchenko (2001) as well as Grassberger and Reiter (2002) calculated the minimum temperature threshold for total immature development of extant Protophormia terraenovae. Based on studies with constant temperatures of $11^{\circ} \mathrm{C}$ to $30^{\circ} \mathrm{C}$ the minimum temperature threshold was calculated to be $7.8^{\circ} \mathrm{C}$ (Marchenko, 2001). Grassberger and Reiter (2002) used constant temperatures of $15^{\circ} \mathrm{C}$ to $30^{\circ} \mathrm{C}$ in their studies and calculated a minimum temperature threshold of $8.95^{\circ} \mathrm{C}$. However, Warren and Anderson (2013) determined the minimum temperature threshold based on studies with constant temperatures of $9.8^{\circ} \mathrm{C}$ to $32^{\circ} \mathrm{C}$ and reported that eggs of extant samples did not hatch at $9.8^{\circ} \mathrm{C}$ and also hatching is not expected at $10^{\circ} \mathrm{C}$. Only at temperatures of $\geq 10.3^{\circ} \mathrm{C}$ egg hatching occurred (Anderson and Warren, 2011). Due to the labour experiments with constant temperatures of Warren and Anderson (2013) the minimum temperature threshold for a complete life cycle of extant Protophormia terraenovae (in British Columbia; Canada) is between $11^{\circ} \mathrm{C}$ and $13^{\circ} \mathrm{C}$ including a mortality 
rate of $96.75 \%$ before reaching the pupal stage. Only constant temperatures at or slightly above $15^{\circ} \mathrm{C}$ allow a rather stable and complete lifecycle (Warren and Anderson, 2013). However, there are no constant temperatures under natural conditions. But in nature larvae of extant Protophormia terraenovae formed a maggot mass after emergence (Wells and LaMotte, 1965; Marchenko, 2001) and increase the carcass' temperature (Payne, 1965). Raised temperatures, up to as high as $45^{\circ} \mathrm{C}$, can be produced inside the core of the maggot cover, even while the ambient temperature is merely $4^{\circ} \mathrm{C}$ to $15^{\circ} \mathrm{C}$ (Marchenko, 2001). As a consequence, the maggots collectively experience better conditions for their development (Marchenko, 2001). This phenomenon is called "maggot mass effect" (Wells and LaMotte, 1995) and is often documented for extant Protophormia terraenovae in cooler regions (Greenberg and Tantawi, 1993). Consequently, Warren and Anderson's data proves that during Eemian and early Weichselian periods with a day-long temperature of more than $10^{\circ} \mathrm{C}$ occurred allowing the development and eclosion of the larvae of Protophormia terraenovae. This assumption is supported by the fact that fly reproduction in moderate climatic zone starts in spring when $24 \mathrm{~h}$ temperature is stabilized at $10^{\circ} \mathrm{C}$ to $15^{\circ} \mathrm{C}$ level and ends in autumn, when temperature drops below $10^{\circ} \mathrm{C}$ to $13^{\circ} \mathrm{C}$ (Vinogradova and Marchenko, 1984).

\section{Taphonomy of Protophormia terraenovae discovered from Megaloceros giganteus}

Most puparia found in the skull of Megaloceros giganteus were filled with the remains of adult blow flies. Hence, these larvae finished their developmental cycle inside the puparia but did not emerge. Thus they were trapped there for fossilization. It is uncertain as to what happened. However, described below are three very plausible scenarios.

Scenario 1. A sudden drop in temperature for a short time period may have inhibited the lifecycle killing most individuals before hatching. Only larvae which developed near the inner core of a maggot mass were strong enough to survive the temperatures below the minimum temperature threshold and emerged. It is known that larvae of extant Protophormia terraenovae would become more resistant to lower temperatures, if they were exposed to slightly higher temperature for a brief while (Anderson and Warren, 2011).

Scenario 2. Parts of the mammal remains (mainly the skulls) were buried by fluviatile sediments at the riverbank by some centimetres and containing puparia with adult blow flies. Under such a scenario, perhaps only a few flies would emerge and reach the surface while the remainder perished. It is known that adult blow flies are able to get out of buried puparia and are able to reach the surface, if the depth is not too great (Fabré, 2003). Experiments of buried blow flies, especially Protophormia terraenovae, showed a survival rate of $84 \%$ at a burial depth of 5 to $25 \mathrm{~cm}$, and of $32 \%$ at a depth of $50 \mathrm{~cm}$ (Balme et al., 2012).

Scenario 3. After reaching the end of the pupal stage some adult blow flies emerged before the water level of the river increased. Mammal remains including the remainder puparia became submerged, and the adult blow flies drowned right before hatching.

Otherwise, the water level of the river increased right before emergence of the adult blow flies and carcasses including the puparia became submerged. If carcasses were washed up after one or four days, some adult blow flies were able to hatch whereas the remainder was drowned. Singh and Greenberg (1994) documented a survival rate of submerged puparia of extant Protophormia terraenovae after four days of $25 \%$, whereas after five days none of them survived.

\section{CONCLUSION}

Based on recent data from the field of forensic entomology, we have attempted to reconstruct the taphonomic histories of the corpse of Bos primigenius, Megaloceros giganteus and both specimens of Mammuthus primigenius from the gravel pits of Groß-Rohrheim and Geinsheim near Darmstadt (Hesse, Germany). Furthermore we give three possible taphonomic scenarios as to why the puparia of Protophormia terraenovae got trapped inside the cranial fragments of Megaloceros giganteus. We do not know when Megaloceros shed its antlers. That would indicate when this animal died. Thus we only can assume roughly that the animals died at any time of the year during the last interglacial (only relevant for Bos primigenius and Megaloceros giganteus) or in the summer months during the early Weichselian glacial. The temperature was at a minimum of about $10^{\circ} \mathrm{C}$ or higher for an eclosion of the larvae. It is assumed that the cadavers were lying on dry ground or in shallow water and were colonized by blow flies. The soft parts were not fully decayed when the carcasses or the crania were brought into the sediment. Most of the individuals of Protophormia terraenovae, found inside the cranial fragments of Megaloceros giganteus, 
seems to be freezed to death by a sudden drop in temperature or drowned in a river flooding or smothered because of burial.

\section{ACKNOWLEDGEMENTS}

We want to thank K. Szpila (UMK, Poland) and J. Amendt (RMIF, Germany) for their help in identification of the fossil puparia. We especially thank K. Szpila for sending us some comparison samples of extant blow fly puparia. We thank G. Oleschinski for taking photographs and P. Göddertz (both StIPB) for technical support. Further, we want to thank J.A. Schultz (UChicago, USA), G. Zazula (Yukon Gov., Canada), D. Mol (NMR, Netherlands), G. Böhme (MfN, Berlin), T. Martin, R. Schellhorn, A. Schwermann, A. Schubert, R. Hielscher, J. Brinkkötter, and F. Stebner (all StIPB) for their input and discussion. We want to thank both anonymous reviewers for their useful comments on the manuscript. In addition we thank both anonymous English correctors. In addition we want to thank H. Reinders (Intern at the Steinmann-Institut) for three-dimensional reconstruction of the cephaloskeleton. The first author especially wants to thank his wife M. Gupta-Mähler for her support.

\section{REFERENCES}

Amendt, J., Krettek, R., and Zehner, R. 2004. Forensic entomology. Naturwissenschaften, 91:51-65. doi:10.1007/s00114-003-0493-5.

Amendt, J., Krettek, R., and Zehner, R. 2005. Forensische Entomologie - Insekten auf Leichen. Biologie in unserer Zeit, 35(4):232-240. doi:10.1002/biuz.200410284.

Anderson, G.S. 2001. Forensic entomology in British Columbia: A brief history. Journal of the Entomological Society of British Columbia, 98:127-135.

Anderson, G.S. and Hobischak, N.R. 2004. Decomposition of carrion in the marine environment in British Columbia, Canada. International Journal of Legal Medicine, 118:206-209. doi:10.1007/s00414-004-0447-2.

Anderson, G.S. and Warren, J.-A. 2011. Establishing lower development thresholds for a common blowfly: For use in estimating elapsed time since death using entomological methods. Defence Research and Development Canada - Centre for Security Science, Contract Report, 2011(23):1-35.

Bader, K.S., Hasiotis, S.T., and Martin, L.D. 2009. Application of forensic science techniques to trace fossils on dinosaur bones from a quarry in the Upper Jurassic Morrison Formation, Northeastern Wyoming. Palaios, 24:140-158. doi:10.2110/palo.2008.p08-058r

Balme, G.R., Denning, S.S., Cammack, J.A., and Watson, D.W. 2012. Blow flies (Diptera: Calliphoridae) survive burial: Evidence of ascending vertical dispersal. Forensic Science International, 216:e1-e4. doi:10.1016/j.forsciint.2011.07.017.

Benecke, M. 1998. Six forensic entomology cases: Description and commentary*. Journal of Forensic Science, 43:797-805.

Benecke, M. 2005. Arthropods and Corpses, p. 207-240. In Tsokos, M. (ed.), Forensic Pathology Reviews, Volume 2. Humana Press, Totowa - New Jersey.

Benecke, M. 2007. Dem Täter auf der Spur: So Arbeitet die Moderne Kriminalbiologie. Verlagsgruppe Lübbe $\mathrm{GmbH} \&$ Co. KG, Bergisch Gladbach, Germany.

Beug, H.-J. 1988. Über die pollenanalytische Datierung einiger jungpleistozäner Proben aus der Oberrheinebene und ihre chronostratigraphische Deutung, p.117-147. In Koenigswald, W.v. (ed.), Zur Paläoklimatologie des letzten Interglazials im Nordteil der Oberrheinebene. Akademie der Wissenschaften und Literatur-Mainz, Gustav Fischer Verlag, Stuttgart.

Böhme, G. 2010. Reste von Fliegenpuppen (Diptera: Calliphoridae) aus den interglazialen Beckenablagerungen von Neumark-Nord bei Merseburg (Sachsen-Anhalt). Veröffentlichungen des Landesamtes für Denkmalpflege und Archäologie, 62:317321.

Bourel, B., Callet, B., Hédouin, V., and Gosset, D. 2003. Flies eggs: A new method for the estimation of shortterm post-mortem interval? Forensic Science International, 135:27-34. doi:10.1016/S03790738(03)00157.

Britt, B., Scheetz, R.D., and Dangerfield, A. 2008. A suite of dermestid beetle traces on dinosaur bone from the Upper Jurassic Morrison Formation, Wyoming, USA. Ichnos, 15:59-71. doi:10.1080/10420940701193284.

Busvine, J.R. 1980. Insects and Hygiene. Chapman and Hall, London. doi:10.1007/978-1-4899-3198-6_1.

Catts, E.P. and Goff, M.L. 1992. Forensic entomology in criminal investigations. Annual Review of Entomology, 37(1), 253-272.

Chin, K. and Bishop, J.R. 2008. Exploited twice: bored bone in a theropod coprolite from the Jurassic Morrison Formation of Utah, U.S.A. p. 379-387. In Bromley, R.G, Buatois, L.A., Mángano, G., Genise, J.F., and Melchor, R.N. (eds.), Sediment-Organism Interactions: a Multifaceted Ichnology. SEPM Society for Sedimentary Geology, Tulsa.

Dominato, V.H., Mothe, D., Avilla, L.S., and BertoniMachado, C. 2009. Ação de insetos em vértebras de Stegomastodon waringi (Mammalia: Gomphotheriidae) do Pleistoceno de Águas de Araxá, Minas Gerais, Brasil. Revista Brasileira de Paleontologia, 12:77-82. doi:10.4072/rbp.2009.1.07.

Fabré, J.H. 2003. Bilder aus der Insektenwelt. FranckhKosmos Verlags-GmbH \& Co., Stuttgart.

Gautier, A. 1975. Fossiele vliegenmaden (Protophormia terraenovae Robineau-Desvoidy, 1830) in een sche- 
del van de wolharige neushoorn (Coelodonta antiquitatis) uit het Onder-Würm te Dendermonde (OostVlaanderen, België). Natuurwetenschappelijk Tijdschrift, 56:76-84.

Gautier, A. 1995. Bovenpleistocene zoogdieren van Oudenaarde Donk (België), fossiele vliegepoppen uit de Vlaamse Valleien elders en nog een en ander over de Vlaamse Vallei. Cranium, 12(2):73-81.

Gautier, A. and Schumann, H. 1973. Puparia of the subarctic or black blowfly Protophormia terraenovae (Robineau-Desvoidy, 1830) in a skull of a late Eemian (?) bison at Zemst, Brabant (Belgium). Palaeogeography, Palaeoclimatology, Palaeoecology, 14:119-125. doi:10.1016/0031-0182(73)90007-2.

Grassberger, M. and Reiter, C. 2002. Effect of temperature on development of the forensically important holarctic blow fly Protophormia terraenovae (RobineauDesvoidy) (Diptera: Calliphoridae). Forensic Science International, 128:177-182. doi:10.1016/S0379-0738(02)00199-8.

Greenberg, B. and Tantawi, T. 1993. Different developmental strategies in two boreal blow flies (Diptera: Calliphoridae). Journal of Medical Entomology, 30:481-484. doi:10.1093/jmedent/30.2.481.

Heinrich, A. 1988. Fliegenpuppen aus eiszeitlichen Knochen. Cranium, 5:82-83.

Hobischak, N.R. and Anderson, G.S. 2002. Time of submergence using aquatic invertebrate succession decompositional changes. Journal of Forensic Science, 47:142-151.

Holden, A.R., Harris, J.M., and Timm, R.M. 2013. Paleoecological and taphonomic implications of insectdamaged Pleistocene vertebrate remains from Rancho La Brea, Southern California. PLOS ONE, 8(7):e67119. doi:10.1371/journal.pone.0067119.

Huchet, J.B. 2014. Insect remains and their traces: relevant fossil witnesses in the reconstruction of past funerary practices. Anthropologie, 52:329-346.

Kabkaew, L.S., Radchadawan, N.-K., Duanghatai, S., and Kom, S. 2007. Identifying fly puparia by clearing technique: application to forensic entomology. Parasitology Research, 101:1407-1416. doi:10.1007/s00436-007-0660-2.

Kaiser, T.M. 2000. Proposed fossil insect modification to fossil mammalian bone from Plio-Pleistocene hominid-bearing deposits of Laetoli (Northern Tanzania). Annals of the Entomological Society of America, 93:693-700. doi:10.1603/0013-8746(2000)093.

Kashyap, V.K. and Pillay, V.V. 1989. Efficacy of entomological method in estimation of postmortem interval: A comparative analysis. Forensic Science International, 40:245-250. doi:10.1016/0379-0738(89)90182-5.

Klinger, R. and Koenigswald, W.v. 1984. Insektenfraßspuren in letztinterglazialen Hölzern aus den
Sanden und Kiesen der nördlichen Oberrheinebene. Eiszeitalter und Gegenwart, 34:131-153.

Koenigswald, W.v. 1988. Paläoklimatische Aussage letztinterglazialer Säugetiere aus der nördlichen Oberrheinebene, p.205-314. In Koenigswald, W.v. (ed.), Zur Paläoklimatologie des letzten Interglazials im Nordteil der Oberrheinebene. Akademie der Wissenschaften und Literatur-Mainz, Gustav Fischer Verlag, Stuttgart.

Koenigswald, W.v. 1991. Exoten in der GroßsäugerFauna des letzten Interglazials von Mitteleuropa. Eiszeitalter und Gegenwart, 41:70-84.

Krause, M. and Jachau, K. 2007. Späte Leichenveränderungen, p. 45-48. In Madea B. (ed.), Praxis Rechtsmedizin. Springer-Medizin-Verlag, Heidelberg.

Langeveld, B. and Mol, D. 2015. Vanuit de zeebodem naar het strand: een kennismaking met fossielien van Maasvlakte 2 (deel 1). Spirifer, 39(5):2-19.

Laudet, F. and Antoine, P.O. 2004. Des chambres de pupation de Dermestidae (Insecta: Coleoptera) sur un os de mammifère tertiaire (phosphorites du Quercy) implications taphonomiques et paléoenvironnementales. Geobios, 37:376-381. doi:10.1016/j.geodios.2003.04.005.

Marchenko, M.I. 2001. Medicolegal relevance of cadaver entomofauna for the determination of the time of death. Forensic Science International, 120:89-109.

Martin, L.D. and West, D.L. 1995. The recognition and use of dermestid (Insecta, Coleoptera) pupation chambers in paleoecology. Palaeogeography, Palaeoclimatology, Palaeoecology, 113:303-310. doi:10.1016/0031-0182(95)00058-T.

Paik, I.S. 2000. Bone chip-filled burrows associated with bored dinosaur bone in floodplain paleosols of the Cretaceous Hasandong Formation, Korea. Palaeogeography, Palaeoclimatology, Palaeoecology, 157:213-225. doi:10.16/S0031-0182(99)00166-2.

Payne, T.A. 1965. A summer carrion study of the baby pig Sus scrofa Linnaeus. Ecological Society of America, 46:592-602. doi:10.2307/1934999.

Plicht, van der H., Post, K., and Mol, D. 2012. Over aasvliegen en een mammoetkalf uit de Eurogeul. Cranium, 29(2):14-19.

Pohjoismäki, J.L.O., Karhunen, P.J., Goebeler, S., Saukko, P., and Sääksjärvi, I.E. 2010. Indoors forensic entomology: Colonization of human remains in closed environments by specific species of sarcosaprophagous flies. Forensic Science International, 199:38-42. doi:10.1016/j.forsciint.2010.02.033.

Reiter, C. and Wollenek, G. 1983. Zur Artbestimmung der Puparien forensisch bedeutsamer Schmeißfliegen. Zeitschrift für Rechtsmedizin, 91:61-69. doi:10.1007/BF01882449.

Roberts, E.M., Rogers, R.R., and Foreman, B.Z. 2007. Continental insect borings in dinosaur bone: exam- 
ples from the late Cretaceous of Madagascar and Utah. Journal of Paleontology, 81:201-208.

Schoch, W.H. 1988. Holzfunde aus den jungpleistozänen Sedimenten der Oberrheinebene, p.149172. In Koenigswald, W.v. (ed.), Zur Paläoklimatologie des letzten Interglazials im Nordteil der Oberrheinebene. Akademie der Wissenschaften und Literatur-Mainz, Gustav Fischer Verlag, Stuttgart.

Schoenly, K.G., Haskell, N.H., Mills, D.K., Bieme-Ndi, C., Larsen, K., and Lee, Y. 2006. Recreating death's acre in the school yard: Using pig carcasses as model corpses. The American Biology Teacher, 68:402-410. doi:10.1662/00027685(2006)68[402:RDAITS]2.0.CO;2.

Schweiss, D. 1988. Jungpleistozäne Sedimentation in der nördlichen Oberrheinebene, p.19-78. In Koenigswald, W.v. (ed.), Zur Paläoklimatologie des letzten Interglazials im Nordteil der Oberrheinebene. Akademie der Wissenschaften und Literatur-Mainz, Gustav Fischer Verlag, Stuttgart.

Singh, D. and Greenberg, B. 1994. Survival after submergence in the pupae of five species of blow flies (Diptera: Calliphoridae). Journal of Medical Entomology, 31:757-759. doi:10.1093/jmedent/31.5.757

Smith, K.G.V. 1986. A Manual of Forensic Entomology. British Museum (Natural History), London.
Szpila, K. 2010. Key for the identification of third instars of European blow flies (Diptera: Calliphoridae) of forensic importance, p. 43-56. In Amendt, J., Goff, M.L., Campobasso, C.P., and Grassberger, M. (eds.), Current Concepts in Forensic Entomology. Springer Science+Buisness Media B.V., Dordrecht. doi:10.1007/978-1-4020-9684-6.

Vinogradova, E.A. and Marchenko, M.I. 1984. The use of temperature parameters of fly growth in the medicolegal practice. Sudebno-meditsinskaia Ekspertiza, 27:16-19

Warren, J.-A. 2006. The development of Protophormia terraenovae (Robineau-Desvoidy) (Diptera: Calliphoridae) at constant and fluctuating temperatures. Unpublished Master's thesis, Simon Fraser University, Burnaby, British Columbia, Canada.

Warren, J.-A. and Anderson, G.S. 2013. The development of Protophormia terraenovae (Robinaeu-Desvoidy) at constant temperatures and its minimum temperature threshold. Forensic Science International, 233:374-379. doi:10.1016/j.forsciint.2013.10.012.

Wells, J.D. and LaMotte, L.R. 1995. Estimating maggot age from weight using inverse prediction. Journal of Forensic Science, 40:585-590. doi:10.1520/JFS13830J. 